\title{
Escritas da história nos anos 1980: um ensaio sobre o horizonte histórico da (re)democratização
}

Francisco Gouvea de Sousa*

Resumo: O objetivo principal deste ensaio é ter a história da historiografia como caminho para reconstruir parte do horizonte da redemocratização, em diálogo com alguns livros que estão presentes na formação de historiadores desde a década de 1990. A atualidade e permanência da produção destes anos sugere a continuidade de um horizonte histórico. $\mathrm{O}$ ensaio realiza então três movimentos: 1) a compreensão da redemocratização como reconstrução de um horizonte; 2) a crise do conceito "ideologia" como sintoma de uma transformação mais ampla; 3) algumas respostas da historiografia à redemocratização. A questão é saber como democracia e historiografia se reorganizaram se abrindo para "novas personagens" e para um horizonte histórico em movimento. Palavras-chave: Anos 80. História da historiografia. (Re)democratização.

\section{Introdução}

Não é por acaso que voltamos nossas expectativas para a década de 1980. Hoje, a necessidade de intensificar a vida pública é urgente, assim como foi na redemocratização. Ainda assim, infelizmente, a redemocratização vivida ao longo dos anos 1980 tem aparecido pouco como experiência em sua pluralidade. As leis de produção popular enviadas ao congresso (uma parte pontual, mas exemplar, da constituinte), as associações de bairro e os movimentos de luta

"Doutor em História pela PUC-Rio; Professor do Departamento de História da Universidade Estadual do Rio de Janeiro - UERJ. E-mail: chico_gouvea@ yahoo.com.br

Anos 90, Porto Alegre, v. 24, n. 46, p. 159-181, dez. 2017 
Escritas da história nos anos 1980: um ensaio sobre o horizonte...

por moradia, a própria invenção do conceito de "movimento social" (uma criação dos anos 1980 viva nos dias de hoje), toda a diversidade da ação parece menor que a importância do texto constitucional ou da eleição de 1989 como marco democrático.

Essa baixa presença da pluralidade de experiências da redemocratização aparece em muitos lugares. Por exemplo, quando eventos recentes, como as jornadas de 2013, são vistas como novidade quando, à rigor, retomam diferentes ações e caminhos que foram vividos na redemocratização (NOBRE, 2013). Parece que entre as gerações - que foram sendo formadas ao longo da institucionalização da democracia - existem lacunas, principalmente no que diz respeito à transferência de experiências de participação ativa na vida pública. Os anos 80 não foram tão diferentes de 2013 e, em outros sentidos, de 2017.

Nos limites deste ensaio, que pretende agir sobre essa perda de experiência geracional, importa principalmente uma questão: a relação entre democracia e incerteza. Ao contrário do que as imagens do fim da ditadura ou da "década perdida" podem sugerir, a década de 1980 foi marcada por dúvidas. Não era evidente o que era democracia, nem o lugar dos partidos políticos. $\mathrm{O}$ voto aparecia como um elemento consensual, assim como a ideia de representação. Mas isso não quer dizer que as suas contradições não fossem discutidas, pelo contrário: "Assim, a hipocrisia aparente que consiste em contar como unidades iguais os votos de cidadãos desiguais é o próprio preço da democracia” (ROUQUIÉ; LAMONIER; SCHVARZER, 1985, p. 23).

O centro do debate era a democracia, mas também seus limites. Parte da dificuldade de se orientar e ter como aliada a pluralidade de experiências da redemocratização vem daí: os anos 1980 falam mais de dúvidas do que de respostas. Se os debates da década giraram entorno da democracia enquanto dúvida, sua fisionomia é mais ou menos estável.

É comum pensar os anos 1980 a partir dos seguintes marcos: a) suspensão do AI-5 (1978) e a anistia (1979), como marcos do suposto fim das estruturas mais duras e autoritárias da ditadura; b) o governo de João Figueiredo (1979-1985), como uma transição democrática; c) a constituição de 1988 e as eleições de 1989 como marcos 
iniciais de uma estabilidade democrática. Essa periodização, porém, dá pouco lugar a duas experiências centrais da década: as "diretas já!” e, principalmente, a constituinte. Essas experiências foram, no limite, diferentes, mas conectadas. As "Diretas Já!” foram vividas como uma derrota, mas uma derrota que animou com muita força a constituinte (VERSIANI, 2014). A redemocratização foi marcada pela presença ativa na vida pública, nas cidades, ruas e bairros.

Por outro lado, mesmo deputados que foram eleitos para atuar na constituinte duvidaram dela. Florestan Fernandes é um bom exemplo. Ao longo da década, ele publicava suas angústias e críticas em jornais e artigos e não deixou de fazer isso quando foi eleito deputado constituinte. $\mathrm{Na}$ condição de deputado, afirmava:

A chamada "conciliação conservadora" tinha por objetivo uma estratégia clara, de natureza político-militar: fechar os horizontes que a crise da República institucional abria para a eclosão das forças populares na cena histórica (ou, como preferiu afirmar o deputado Ulysses Guimarães, na qualidade de presidente do PMDB, propor uma escolha que contornasse as "explosões sociais")". (FERNANDES, 1989, p. 27).

Nos limites deste ensaio, não interessa tanto um debate sobre o quanto de fato ocorreu de participação direta na constituinte ou não. $\mathrm{O}$ que interessa é a presença da dúvida. $\mathrm{O}$ mais importante é esse gesto crítico que coloca questões ao auditório, mas não dá uma diretriz imediata ou uma resposta única - cobrando, assim, autonomia do interlocutor. Florestan Fernandes, ou qualquer outro que falasse da redemocracia como um debate e uma questão em aberto, estava sendo cético. Nos limites desse ensaio, cética é toda voz que se esforçava em falar de democracia como incerteza e, ao que parece, muitas se esforçaram para isso. É nesse sentido que a dúvida e a crítica de Florestan Fernandes interessam aqui.

No caso da historiografia, ceticismo foi a complexificação de passados que eram vistos, nos debates públicos, como homogêneos, um passado arcaico que tornava todo o passado um tempo perdido. $\mathrm{O}$ que a historiografia fez foi colocar em aberto o que 
Escritas da história nos anos 1980: um ensaio sobre o horizonte...

se sabia sobre o passado. Pelo menos, é claro, nos principais textos para esse ensaio: $O$ diabo e a Terra de Santa Cruz (1986) de Laura de Mello e Souza; O Tempo Saquarema (1994), de Ilmas Mattos; $A$ invenção do trabalhismo (2005), de Ângela de Castro Gomes; Os Bestializados (1987), de José Murilo de Carvalho.

O objetivo principal deste ensaio e dessa seleção é ter a história da historiografia como caminho para reconstruir laços geracionais por de dentro de alguns livros que estão presentes na formação de historiadores a partir da década de 1990. Ler a escrita da história dos anos 1980 em seu horizonte implica também em um gesto cético: colocar em movimento textos que são lidos como referências estáveis. Não na pretensão da superação por novas e atuais pesquisas - como se fôssemos sempre obrigados a desfazer o que foi feito para dar chance ao novo - mas pela compreensão deles em seus horizontes. Assim, talvez apareça o quanto as nossas referências são da redemocratização. A atualidade e permanência da produção destes anos se deve, ao que tudo indica, à continuidade de um horizonte.

No horizonte da redemocratização existe ainda outra experiência incontornável que ainda ecoa: a dissolução de diferentes expectativas de futuro e um clima de estagnação. De início, pode parecer que isso afetou mais diretamente aqueles que se compreendiam como de esquerda, mas não é o caso. A dissolução da URSS marcou a todos. Num contexto amplo, é possível pensar a década de 1980 e a redemocratização como parte de uma "experiência abismal", que quer dizer: aparente perda de horizonte de inteligibilidade. $\mathrm{Ou}$ seja, o futuro que se imaginava até o fim da URSS era um, depois do fim da Guerra Fria ele teve de ser reconstruído. Pelo conceito de "experiência abismal" (de se estar de frente para o abismo), Elias Paltí inicia Verdades y saberes del marxismo (2010), para falar de como a experiência vivida pela dissolução de expectativas marxistas não diz respeito apenas aos marxistas. Este texto não seria possível sem esse livro, nem o seu caminho principal: a diferença entre verdade - o marxismo como uma prática política - e o saber - o marxismo como um sistema de conhecimento.

Essa diferença é importante na medida em que no Brasil aconteciam ao mesmo tempo o fim da URSS e a redemocratização. $\mathrm{O}$ marxismo foi revisto enquanto prática política e como conhecimento. 
De forma esquemática, na luta contra os regimes militares o elogio à democracia se tornou uma demanda, o que implicava rever conceitos como democracia burguesa e, até mesmo, classe. Nas escritas da história, por sua vez, o marxismo como saber também sofria mudanças que pretendiam, falando de forma ampla, dar voz e lugar a "novos sujeitos históricos". A historiografia estava em diálogo com a verdade, com a prática, mas mantinha uma autonomia que, por caminhos diferentes dos deste ensaio, já foi alvo de pesquisa.

O interesse por essa historiografia da década de 1980 não é um interesse novo. Indo a uma das primeiras reflexões sobre o tema, Carlos Fico e Ronald Polito (1992) mostram, com um levantamento amplo de revistas, dissertações e teses, que nos anos 1980 começam a se estabelecer as pós-graduações em história de forma mais intensa e, assim, a dinâmica da produção científica em história começa a entrar numa lógica que em breve seria operacionalizada pelas agências de fomento como CAPES e CNPq. O que implica, por exemplo, numa maior ênfase na produção de artigos especializados e numa menor dedicação à divulgação científica ou à produção de materiais didáticos, algo que está longe de ser específico da história.

A tese de Igor Guedes Ramos (2014) é, provavelmente, o trabalho mais atual e completo sobre a historiografia da década de 1980, especialmente no que diz respeito às recepções de Thompson e de Foucault. Essa escolha desarma, e isso é fundamental, a imagem de que a década de 1980 foi o momento da recepção da chamada terceira geração dos Annales - o que é apenas uma das afirmações dos Annales como formadores da historiografia contemporânea, discurso que ganha força, ao que tudo indica, a partir da década de 1990.

O que esse artigo acrescenta pontualmente ao debate é o quanto o horizonte da historiografia não era construído centralmente por referências, mas pela própria experiência da redemocratização. A busca por este horizonte, então, implica sair da historiografia e ir aos debates sobre a redemocratização sem perder de vista que o que interessa é o horizonte destes. Vale saber o que diziam personagens como Raimundo Faoro ou Marilena Chauí. Também é neste horizonte que a história se renovava.

Para falar sobre esses pontos, o texto se divide em três questões: 1) um panorama da redemocratização como uma experiência 
Escritas da história nos anos 1980: um ensaio sobre o horizonte...

abismal (PALTí, 2010); 2) a dissolução da unidade do conceito de ideologia como índice de uma dupla crise: epistemológica e do lugar ocupado pelo intelectual/historiador; 3) algumas respostas dadas pela historiografia e o seu ceticismo.

\section{A experiência, o abismo e a democracia}

A produção da década de 1980 sobre democracia não caberia num texto. Mas duas referências podem ajudar na construção de um panorama: um ensaio chamado $A$ democracia como valor universal (1979), de Carlos Nelson Coutinho - tradutor e comentador de Antonio Gramsci; e o livro A democracia e os comunistas no Brasil (1980), de Leandro Konder - leitor e divulgador de Walter Benjamin. Ambos marcam justamente o quanto existe de uma experiência de perda de futuro sendo reconstituída pelo conceito de democracia nessa década. Ambos abandonam qualquer projeto revolucionário ou esquema explicativo estável para investir no político, compreendendo este investimento, na prática, como defesa da democracia. No limite, era do próprio conceito moderno de "revolução" (KOSELLECK, 2006) que eles se afastavam. Ao mesmo tempo, dava-se um afastamento de qualquer crítica direta à propriedade privada.

O primeiro, o afastamento do conceito de "revolução", era evidente. Seja para Konder, ou Nelson Coutinho, existe uma visível expectativa de repensar práticas da esquerda, principalmente o suposto uso "estratégico" da democracia. Isso implica um certo esvaziamento do futuro como meta para uma atenção dedicada ao presente e à política. Era também uma necessidade do momento. Depois do golpe de 1964 - que se apropriou de muitas formas do conceito moderno de "revolução" - não era fácil defender a imagem de um gesto violento que separa o presente do futuro. Para esses dois textos, a democracia era uma meta e um meio, a abertura para a vida política era um caminho para refundar uma dimensão de verdade, era uma outra prática, definitivamente dedicada à política compreendida como dirigir, pensar e disputar o Estado nas contingências do presente. Era, também, uma pretensão de alargamento 
do que se compreende por democracia. "A ideia dessa articulação entre democracia representativa e democracia direta já faz parte do patrimônio teórico do marxismo" (COUTINHO, 1979, p. 38).

No segundo caso, o afastamento da crítica à propriedade privada produz um esquecimento em relação à tradição e uma profunda dificuldade em ler Marx diretamente, como se a cada momento algo de não contemporâneo devesse aparecer. Semelhante ao que Paltí (2010) vê em Nahuel Moreno, a crise da URSS não era vista como um limite para o marxismo em geral. O fim da URSS era, no limite, o fim do stalinismo e de suas formas de saber. Era a chance de uma expansão de outros saberes e outras verdades, como para a radical atenção à história como atenção ao político que, aqui, não seria compreendido jamais como consequência de uma estrutura ou como pura e simples ideologia. Ao pensar a política como contingência e aberta a disputa, o marxismo rompia com qualquer compreensão da história por etapas ou modelos. Léon Trotsky e Antonio Gramsci seriam fonte de renovação, mas o futuro não seria mais socialista. Pelo menos não um futuro próximo. Assim, o conceito de revolução em sua formulação moderna - como uma separação radical entre dois momentos da história - perdia espaço e, no mesmo movimento, a história do Partido Comunista Brasileiro (PCB) se tornava um exemplo, um passado que precisava ser digerido.

Os erros do passado se tornavam um tema recorrente em escritas da história do PCB publicadas ao longo dos anos 1980. Em sua Contribuição à história do PCB (1984), Nelson Werneck Sodré falava de mais de quarenta livros sobre o tema. A história do PCB parece ter sido um gênero. No geral, o que aparece é a necessidade de produzir sentido exemplar para o passado, como se a única forma de produzir sentido fosse aprendendo com erros do PCB.

As escritas que narravam as experiências ao longo da ditadura, como testemunhas do que foi vivido, por sua vez, são como testes constantes da capacidade de produzir sentido para a história. São outro gênero constante nos anos 1980, manifestação da perda de horizonte pela experiência dos regimes militares. Não há como subestimar o quanto de perda de hozironte não se devia à própria experiência da ditadura. Escrito por Jacob Gorender, membro do PCB, Combates nas trevas (1987) - que é a princípio um relato 
Escritas da história nos anos 1980: um ensaio sobre o horizonte...

biográfico, mas acaba sendo também uma história do PCB - mostra o quanto existe de suspensão de sentido na própria organização do livro. A história do PCB, e a dificuldade em contá-la, era como que misturada à própria experiência de viver a prisão, a tortura, a perda de companheiros e companheiras. A prisão simplesmente irrompe em um capítulo, interrompendo de um golpe só uma narrativa que até então era sequencial e causal. Os erros, ou o erro central (a hierarquização interna do partido competia com a aposta numa aliança com a burguesia nacional como erro fatal do PCB), falavam de uma falta de atenção com o fím do populismo, solo histórico dos regimes militares na compreensão de Gorender. Existia um processo histórico a ser percebido, mas não foi. A compreensão da história podia falhar. $\mathrm{O}$ tempo ainda era moderno, mas a confiança na consciência histórica estava em suspenso.

O debate pela democracia, porém, era bem mais amplo. Com o fim anunciado da Guerra Fria, democracia não poderia mais ser o oposto do comunismo ou de uma liberdade Antiga ${ }^{1}$. Mas essa estatura foi na verdade uma dúvida constante para muitos que, desde a suspensão do AI-5 e da Lei de Anistia, começaram a debater intensamente o tema em espaços como o Centro de Estudos de Cultura Contemporânea (CEDEC), ou o Centro Brasileiro de Análise e Planejamento (CEBRAP), próximos, principalmente, pela figura de Raimundo Faoro a OAB (FAORO, 1981). Inclusive por sua atuação ao longo dos regimes militares na defesa de presos políticos, Faoro era como um patrono destes espaços em que se discutia a redemocratização.

Entre tantos que estavam juntos dele, numa posição bem distinta daquelas de Carlos Nelson Coutinho e Leandro Konder, Bolivar Lamounier (1985) agia sobre um mosaico que resume muito da experiência de perda de horizonte. Não havia consenso sobre a forma dos partidos (se pluripartidarismo ou bipartidarismo) ou sobre as diferentes formas de processos eleitorais. O significado das ações diretas em São Paulo e Brasília era radicalmente distinto do que se vê hoje. Quando a violência irrompia, para Lamounier (1986), era evidente a falha do Estado, o quebra-quebra era um código e não uma alteridade. Por sua vez, a tolerância ao uso da violência no 
espaço público era proporcional à tolerância com a naturalização da desigualdade social.

Essa descrição ampla do consenso sobre a democracia é importante, mas não foi apenas a paisagem quem deu unidade e sentido à redemocratização. $\mathrm{O}$ consenso sobre o voto era uma parte da questão. A construção da democracia como futuro e valor - o que é comum a Lamounier ou Coutinho, apesar da grande diferença entre ambos - era possível também na medida em que ela era uma diferença em relação a alguma coisa, não mais o oposto do socialismo ou do Antigo, mas o oposto de um passado até aquele momento insuperável. No debate público que se intensificou após a anistia de 1979, não estava em jogo incidir sobre o passado recente, sobre a força que os herdeiros dos regimes militares visivelmente tinham na redemocratização, mas sobre um passado visto como unidade, como arcaico.

Uma referência sistematicamente citada é Vitor Nunes Leal, Coronelismo, enxada e voto (2012), como se as incoerências da primeira república fossem um DNA, algo que explica a carência da democracia como um todo no país. O voto de cabresto é o índice primeiro de um interminável passado arcaico que domesticava o espanto com o passado recente. $\mathrm{O}$ voto de cabresto é tudo o que a redemocratização queria combater como horizonte, inclusive numa reorientação do que seja o voto.

Assim, um otimismo realista ia se formando na redemocratização, um otimismo que só conhece o tempo lento justamente por admitir o peso que o passado é. Por sua vez, ao admitir a natureza autoritária do Estado brasileiro como traço constante, a própria ditadura perdia sua excepcionalidade e se tornava uma das manifestações cruéis de nossas tradições autoritárias. A consequência do passado arcaico é a abertura na democracia para o convívio com o que, a princípio, ela se propõe a superar. Em mais de um sentido, o passado arcaico dava uma identidade da democracia e tirava dela a dúvida.

O que se dava até o abismo se confirmar, em 1991 com o fim da URSS, é o que mais interessa: uma certa capacidade de "manter as coisas incertas" (GADAMER, 1997). Antes do fim das expectativas, 
Escritas da história nos anos 1980: um ensaio sobre o horizonte...

mas já com o fim anunciado, a dúvida era uma constante. Era evidente para quem viveu os anos 1980 que a Guerra Fria chegaria ao fim. É esta experiência que interessa principalmente: como agir quando não se confia na resposta? Como falar para outras gerações desta capacidade que parece ter sido perdida?

\section{Crises do conceito de ideologia}

A recepção de autores como Michel Foucault ajudaria a dissolver o conceito de ideologia. Aliás, a sua recepção deu certa fisionomia à maneira como o giro linguístico se daria por aqui (CEZAR, 2015). A adesão mais intensa ao giro linguístico dependia, porém, de uma vinculação com outras referências - como a teoria literária ou sociológica - que organizavam caminhos para colocar os pressupostos dos historiadores em questão (ARAUJO, 1988). A recepção direta da virada linguística, assim, foi baixa. Dentro do debate sobre a recepção do giro linguístico no Brasil, esse texto apenas pontua que a recepção de Gramsci - que não é um autor usual para se pensar a virada linguística - nesses anos tem um efeito que não pode ser desconsiderado.

Quando se distingue entre intelectuais e não intelectuais, faz-se referência, na realidade, tão somente à imediata função social da categoria profissional dos intelectuais, isto é, leva-se em conta a direção sobre a qual incide o peso maior da atividade profissional específica, se na elaboração intelectual ou se no esforço muscular-nervoso. Isto significa que, se se pode falar de intelectuais, é impossível falar de não intelectuais, porque não existem não intelectuais. (GRAMSCI, 1968, p. 7).

Deve-se notar que a elaboração das camadas intelectuais na realidade concreta não ocorre num terreno democrático abstrato, mas de acordo com processos históricos tradicionais muito concretos. Formaram-se camadas que, tradicionalmente, "produzem" intelectuais... (GRAMSCI, 1968, p. 10). 
Quando Gramsci aparece na bibliografia de uma obra dos anos 1980, é pouco provável que Os intelectuais e a organização da cultura (1968) não esteja presente. Essas duas citações, extraídas desse livro, mostram algo, um deslocamento do lugar do intelectual, expõem o quanto a sua posição de destaque é uma construção histórica que se constrói a partir da divisão social do trabalho mais básica: a separação entre trabalho com o corpo e trabalho intelectual. A desestabilização desse lugar produziu uma amplificação das vozes, afinal, na compreensão de Gramsci, todos são intelectuais.

No caso específico da história, algo semelhante acontece pela leitura cada vez mais intensa de E. P. Thompson. No mínimo, a compreensão de formas de dominação ou poder não se daria mais pela compreensão de estruturas previamente definidas. Classe se daria, a partir daí, dentro da história. Não há modelos aqui, apenas a crítica a eles. Mas o que se compreendia por ideologia quando o conceito era estável e uma unidade?

Marilena Chauí, neste ponto, é um índice importante. Além de ter escrito história tendo ideologia como conceito chave (CHAUÍ; FRANCO, 1978), sua definição do conceito é representativo, principalmente no volume $O$ que é ideologia? (1981) da coleção "Primeiros passos”, editada pela Editora Brasiliense. Chama a atenção a presença dessa editora na década não só na produção de materiais de divulgação de conhecimento, como de debates políticos. A coleção "Primeiros passos" é um bom exemplo, mas, como ela, ocorreram várias iniciativas de intervenção nisso que hoje chamamos de história pública.

Essa coleção "Primeiros Passos", aliás, tem servido como uma espécie de dicionário filosófico dos anos 1980 para a pesquisa em curso. Produzida ao longo da redemocratização - ao lado de outras coleções - a coleção "Primeiros Passos" operava como um dicionário, produzindo a tentativa de cristalizar conceitos que, naquele mesmo momento, estavam tendo sentidos deslocados. Nesse sentido, Chauí definia o conceito na seguinte direção, na escrita dirigida a públicos iniciados, sua definição é:

O campo da ideologia é o campo do imaginário [...], não no sentido de irrealidade ou de fantasia, mas no sentido de 
Escritas da história nos anos 1980: um ensaio sobre o horizonte...

conjunto coerente e sistemático de imagens ou representações tidas como capazes de explicar e justificar a realidade concreta. Em suma: o aparecer social é tomado como o ser do social. (CHAUÍ, 1989, p. 19).

Na escrita dirigida a um público amplo, que é o caso da coleção "Primeiros passos", depois de percorrer uma história do conceito, ideologia assume fisionomia por uma narrativa dos diferentes momentos da divisão social do trabalho. A autora seguia de perto a própria estrutura do texto de Marx e Engels. No fim, a questão central também é próxima: a potência de conceitos que, quando generalizados na sociedade, naturalizam a estruturação da mesma. O conceito de propriedade privada, aqui, é o conceito central.

A escrita de Chauí nessa década foi ampla. Incluía também a escrita de prefácios, inclusive de livros de história. E é na escrita de prefácios que sua definição de ideologia dialoga mais diretamente com a historiografia, o que acontece numa história dedicada aos "vencidos". Todos que não eram, até o momento, sujeitos ou protagonistas nas escritas da história.

A "história dos vencidos", antes de ser escrita da história, foi uma crítica à produção acadêmica. "Trata-se, antes de mais nada, de pôr em dúvida a historiografia existente, assinalando seus compromissos (voluntários ou involuntários) com o saber da classe dominante" (CHAUÍ, 1981, p. 11). A historiografia era suspensa por ser instrumento ideológico, principalmente a pretensamente crítica. Duas citações de um livro prefaciado pela autora resumem a questão:

As análises teóricas que se seguiram ao golpe de 1964 enquadraram numa dimensão de vencidos a classe operária e os projetos políticos dos intelectuais, e nessa medida um 'fato político' se fixou como referência universal àqueles que se pretendiam opositores do regime. (DECCA, 1981, p. 32).

Essa totalização, própria a uma certa noção de objetividade da ciência - enquanto esfera especializada do saber -, ao recorrer à classe operária ou ao movimento operário como objetos, como abstrações, silenciou os ecos da experiência 
proletária marcada desde a sua instituição pelo signo da diferença. (DECCA, 1981, p. 34).

O interesse pela experiência é justamente o interesse pela história ainda não conhecida, pelo que não é possível de conhecer ou deduzir a partir de modelos. A esta altura, a própria ciência era ideologia, ao ponto em que todo conhecimento poderia se tornar suspeito e questionável. Esse movimento, da crítica a uma forma de produção de discurso à crítica à produção de discursos em geral, não foi exclusivo da história dos vencidos (ARAUJO, 2012).

Junto da história dos vencidos, Chauí celebrava um livro que afirmava uma nova forma de movimento social, Quando novos personagens entraram em cena, de Éder Sader (1988), em diálogo direto com o ensaio de Carlos Nelson Coutinho. O que chama mais a atenção de ambos (Chauí e Sader) é justamente o quanto as identidades, formas de organização e teorias que definiam as diferentes posições das esquerdas até então perderam sentido para as novas personagens. Era uma nova forma de se organizar que não se orientava por nenhum esquema já conhecido. Todo saber estava em suspenso, a única certeza era a verdade de que novas igualdades haveriam de ser formuladas.

Ao mesmo tempo em que essa reformulação se dava, a escrita da história também se abria para novas vozes. Essa abertura não foi, então, apenas construída pela recepção de Thompson ou de qualquer outra referência, mas também pela própria experiência da redemocratização. Assim como no debate sobre o presente, as escritas sobre o passado se abriam para "novos sujeitos históricos".

A história dos "novos sujeitos", que ganha ampla projeção ao fim da década de 1980, apesar de também se interessar pelos "vencidos”, caminha por outras escolhas. O desejo de falar de quem ainda não era assunto na história é algo que se mantém. A crítica direta à produção universitária não aparece, pelo contrário, existe uma confiança na escrita cientificamente orientada desde que dedicada a falar de quem, até então, não era visto como sujeito histórico. A pergunta central seria sobre como falar desses novos sujeitos. E, assim, uma outra dimensão crítica ao conceito de ideologia apareceu. 
Escritas da história nos anos 1980: um ensaio sobre o horizonte...

\section{Algumas respostas da historiografia}

$\mathrm{Na}$ abertura de $O$ diabo e a terra de Santa Cruz, num momento de demarcação aberta de uma diferença, é dito:

[...] acreditava que a feitiçaria exercida por esses homens pobres - livres, escravos e libertos - apresentava elementos predominantemente africanos. Sobre eles incidia a carga reprobatória dos poderosos e também a do homem comum, que na condenação de seus iguais buscava identificação com as camadas dominantes e introjetava sua ideologia. (SOUZA, 1986, p. 15).

Porém, o caminho da tese foi outro. Foi no romper com o conceito de ideologia que apareceram os "níveis culturais múltiplos, agentes de um longo processo de sincretização" (SOUZA, 1986, p. 16). A ruptura da unidade, prefigurada no conceito de ideologia, é justamente o solo para o florescimento de conceitos como sincretismo, circularidade, troca, negociação, de diversidade interna, mas que carregam um mesmo código: o par dentro e fora é constantemente agredido pela narrativa, implicando uma desestabilização do par em cima e em baixo. De forma que o popular, por não estar totalmente ausente do dominante, subverte e afrouxa estruturas e padrões previamente apresentados. Como se a escrita se dispusesse a escrever tipos e formas de relação de poder para depois constrangê-los.

No limite, o livro atendia a demandas que construía na sua própria trama interna sem deixa de dialogar com esse horizonte mais amplo que se interessava por multiplicar as vozes, no caso, do passado. O diabo e a terra de Santa Cruz (1986) se interessava e construía um percurso para falar do que Decca chamava de diferença: tudo aquilo que se perde quando se define a história por estruturas ou modelos. $\mathrm{E}$ isso tudo era possível e acontecia como afastamento do conceito de ideologia na medida em que ele, inclusive na definição que Chauí reafirmava, colocava política e cultura como subordinadas as estruturas. O conceito de ideologia, porém, não foi apenas suspenso, também foi reformulado. 
Também numa tese defendida na USP, em O Tempo Saquarema (1994), ideologia não era apenas repensada. A recepção de Gramsci é uma marca no livro, por exemplo, em seu uso do conceito direção que marca uma diferença com o conceito de ideologia, mas não é possível resumir a questão apenas a um efeito da recepção de Gramsci. Existe muito do horizonte da redemocratização em O Tempo Saquarema.

Nos limites deste artigo, vale uma síntese extraída de uma referência bibliográfica deste livro para marcar a diferença entre os textos lidos de Gramsci e o horizonte da redemocratização:

Para que haya pensamiento revolucionario tiene que haber ruptura con la estructuración del pensamiento culturalmente consagrado. Y para que el pensamiento revolucionario se logre, esa ruptura tiene que responder a la naturaleza de las cosas. (SÁCRISTAN, 1970, p. 2).

A diferença mais evidente é o conceito de revolução em sua formulação moderna. Essa citação, que abre uma antologia de Antonio Gramsci, não fala diretamente ao horizonte da redemocratização na medida em que o conceito moderno de revolução estava progressivamente perdendo força, mas ainda ecoava. Porém, sem uma referência direta à revolução ou a um horizonte revolucionário, as duas sentenças são muito próximas ao que, neste ensaio, é entendido como democracia enquanto dúvida: 1) "deve haver uma ruptura com a estruturação do pensamento culturalmente consagrado"; 2) "essa ruptura deve responder à natureza das coisas". Imerso neste horizonte, O Tempo Saquarema (1994) é tanto uma interpretação histórica quanto um percurso formativo. Ele expõe como o "pensamento" se torna "culturalmente consagrado", sem perder de vista que esse processo se dá historicamente, em condições concretas e contraditórias. Essa postura marca, inclusive, a forma como o livro se coloca em relação às diferentes tradições que o perpassam.

De forma mais direta que em $O$ diabo e a terra de Santa Cruz, inclusive em suas notas de pé de página, O Tempo Saquarema (1994) dialoga com diferentes debates brasileiros da década de 1970 e também com dilemas da historiografia da já corrente 
Escritas da história nos anos 1980: um ensaio sobre o horizonte...

década de 1980 - é importante não esquecer que as teses, nesses anos, tinham uma duração mais extensa e acumulavam sobre si diferentes ritmos e camadas.

Se ao longo da década de 1980 a teoria da dependência perde parte de seu sentido justamente porque os conceitos que lhe davam sentido estão instáveis, O Tempo Saquarema (1994) não abre mão do que foi produzido antes - o que fica evidente no seu $1^{\underline{a}}$ capítulo. A particularidade do livro está também em sua capacidade de transferir debates anteriores sem ser apenas atualização. O Império aparece inicialmente como recunhagem de uma economia colonial para, depois, ter uma fisionomia política própria. Aqui as referências podem ser de Caio Prado a Fernando Novais. Não importa tanto, neste ensaio, em qual tradição se ancora, e sim como se comporta em relação a ela. A dimensão assimétrica, assim como foi da relação entre colônia e metrópole, permanece; mas não define a história. É uma das perspectivas necessárias para se compreender a construção do Estado, mas não é totalizante. As estruturas não explicam ou definem a história.

Ao mesmo tempo, tanto o segundo quanto o terceiro capítulo investem diretamente nas consequências de ver o conceito de classe por um caminho diferente: por vozes do passado que se percebem historicamente. É por se verem em risco, por se verem como contingências que luzias e saquaremas negociam a formação de uma classe senhorial, negociação assimétrica entre perdedores e vencedores. A direção saquarema se dá pela consciência dos sujeitos, por estes se verem como históricos, por se verem numa transação.

Fora da experiência não é possível saber apenas pela presença de um Estado se há ou não classe. Aliás, a própria compreensão do conceito de Estado como histórico - argumento central da abertura do livro - suspende qualquer possibilidade de relação causal entre classe, Estado e sociedade. É historicamente que se dá a diferença entre ordem e desordem - capaz de normatizar os corpos em seus mundos a partir da cor da pele. O escravo no trabalho. A boa sociedade no governo, na corte, nos comércios, nas letras e espadas. Os homens livres e pobres como fora de ordem, como suspeitos. Os mundos do Império não são categorias estáveis, mas a atualização de estruturas que se dão historicamente, são fruto do olhar 
que os próprios luzias e saquaremas compartilharam. No limite, o objetivo é mostrar esses mundos para que, assim, seja possível perguntar o quanto deles ainda existe em nós. Simultaneamente, aprender a perceber a direção saquarema é uma formação cética, é aprender a suspender juízos estabelecidos sem supor que a saída para eles já esteja dada.

Isso significa, e isso é importante para pensar a redemocratização, que existiu uma sociedade civil, uma vida ativa, uma classe senhorial. Não era possível supor que o passado era apenas um desacerto, um passado arcaico que só produziu sistemas falhos ou o uso impróprio de ideias. As consequências desse passado, o quanto ainda estamos sob o efeito dele ou não, era uma questão.

Esses dois livros são amostras de um horizonte. Também decorrente de tese de doutoramento e presente em nossas graduações, $A$ invenção do trabalhismo (GOMES, 2005) produz uma crítica ao conceito de ideologia por outro caminho: suspende a estabilidade da compreensão da política como populismo, que a essa altura era das molduras principais do passado arcaico. Não que o livro se construa sobre um vazio bibliográfico, ou seja, a inauguração solitária de um campo de pesquisa - seria necessário outro tipo de esforço para investigar como $A$ invenção do trabalhismo (GOMES, 2005) se ancora em tradições - o ponto é mostrar que nos limites da compreensão da Era Vargas era possível identificar a natureza desse passado arcaico que a democracia como valor universal pretendia superar, mas de quem, à rigor, dependia para ter sentido enquanto projeto.

Um dos pontos mais importantes foi a presença das vozes dos sindicatos em movimento. Este movimento é cético também no sentido que essas vozes normalmente não apareciam diretamente. Ao colocar as vozes dos sindicatos no texto sem submetê-las a modelos ou definições prévias do que é consciência, $A$ invenção do trabalhismo (GOMES, 2005) desarma a compreensão da história do século XX no Brasil pela chave do populismo - que colocava os sindicatos como centralizados pelo Estado e, assim, como sujeitos históricos secundários. Mais uma vez as estruturas não definiam a história e, assim, novas personagens entravam em cena. 
Escritas da história nos anos 1980: um ensaio sobre o horizonte...

Talvez seja necessário novamente indicar que a importância de Vitor Nunes Leal, em seu clássico Coronelismo, enxada e voto (2012), não estava tanto no que se compreendia sobre a Primeira República a partir dele, mas no quanto o que era descrito no livro se expandia para além do que o livro pretendia. Nesse horizonte - contra o qual $A$ invenção do trabalhismo (GOMES, 2005) se levantava - toda a República aparecia, até a década de 1980, como marcada pela inverdade, por uma carência. Mesmo a democracia, nesse horizonte, teria de conviver com o autoritarismo. $\mathrm{O}$ passado arcaico era o caminho para permear o consenso pela democracia com diferentes formas de autoritarismo - a condução "por cima" da redemocratização é, talvez, apenas um exemplo.

Era contra esse horizonte formado pelo passado arcaico que parte da historiografia se mobilizava, sem importar se o tema era colônia, império ou república. Dizer que existem momentos de voz ativa no passado, ao mesmo tempo catalisa a redemocratização e complexifica o passado que lhe dava sustentação. Mas a escrita da história não era apenas ceticismo.

Em diálogo com uma tradição weberiana que passa de Sérgio Buarque a Raimundo Faoro, Os Bestializados (CARVALHO, 1987) talvez seja o texto aparentemente mais cético no sentido em que, nele, só existe cidadania a despeito do Estado. A ideia central - que perpassa a grosso modo essa tradição - é que na carência de uma sociedade civil forte, um Estado autoritário se afirma. A República é definida, então, pelas qualidades que lhe faltam. Essa forma de definir a República no Brasil pela negativa só não aparece, em $O s$ Bestializados (1987), quando se pergunta pelo povo, pelos bilontras. Os Bestializados (1987) tem, assim, quase que duas teses diferentes. De um lado aparece sistematicamente a imagem de uma República carente, insuficiente, de uma sociedade civil frágil. De outro, uma cidadania que silenciosamente vai se formando no interior dessa República, muitas vezes contra o Estado.

$\mathrm{Na}$ diferença entre bestializados e bilontras aparece uma forma típica, uma cidadania nascida pelo vácuo e pela violência do Estado. Uma cidadania construída para sobreviver ao Estado. A tematização dos bilontras - que conecta diretamente o livro à experiência 
da redemocratização - como escuta do silêncio dos vencidos tem um sentido diferente da forma como a República é apresentada ao longo do livro. $\mathrm{Na}$ forma como a República era lida, a experiência nacional só tinha sentido quando comparada a um quadro mais amplo. "Mesmo quando determinada mentalidade de uma época é percebida em sua singularidade, tal singularidade sobressai em relação à mentalidade racional moderna" (SALLES, 2012, p. 211). $\mathrm{O}$ universal aparece como um pano de fundo que dá sentido ao singular, um "referente silencioso" (CHAKRABARTY, 2000) que nunca é esquecido e frente ao qual a experiência nacional ganha sentido (SANTOS; NICODEMO; PEREIRA, 2017). De um lado os bilontras, de outro a República que os bestializava.

\section{Os tempos perdidos e uma conclusão}

Se revolução era um conceito que perdia sentido - seja pela própria redemocratização, seja pelo fim da URSS -, o futuro que impulsionava o horizonte revolucionário se mantém, só que desacelerado. E aqui, que se leve em conta a diversidade das posições políticas, a democracia era um debate que pretendia, sobretudo, construir lentamente bases para um futuro. Por mais que o tempo da notícia ocupasse a vida política intensamente em seu incessante atualismo, nos debates sobre a democracia existia também uma atenção ao que ficava para depois. A voz de Florestan Fernandes (1989) falava disso. A constituinte foi um projeto para si e para as próximas gerações.

Nos debates públicos, esse tempo lento da democracia como dúvida e como horizonte foi sendo minado pelo passado arcaico. A afirmação de uma natureza autoritária no passado obrigava a democracia a conviver com este autoritarismo. Era o passado arcaico quem dava a medida da realidade, essa fisionomia nacional que desconhece qualquer história na medida em que o passado ganha sentido como carência, como falta. Neste movimento, a própria excepcionalidade dos regimes militares se desfazia. Ao mesmo 
Escritas da história nos anos 1980: um ensaio sobre o horizonte...

tempo, a democracia deixava de ser dúvida e começava a ter um sentido definido: superar esse passado.

As respostas da historiografia à redemocratização vão se formando por esses diferentes movimentos e, por vezes, contra eles. $\mathrm{O}$ que existe de mais evidente entre a redemocratização e a historiografia é o interesse por novas personagens. No detalhe os conceitos são diferentes, mas não deixa de chamar a atenção que a redemocratização foi o berço de conceitos como "movimento social” e, simultaneamente, de escritas da história que pretendiam colocar na cena personagens que, até o momento, eram considerados como secundários.

Por outro lado, acontecia um exercício sistemático de complexificação do passado, principalmente quando se deixava de definir Estado ou classe por modelos para defini-los pelas experiências dos sujeitos. A historiografia enfrentava, assim, o passado arcaico que era, sobretudo, formado por um "referente silencioso" (CHAKRABARTY, 2000), por uma remissão implícita a modelos universais e eurocentrados que explicam toda diferença. A historiografia recolocava a dúvida no centro. $\mathrm{O}$ interessante do gesto cético, de todo esforço de suspender um juízo sem colocar uma resposta definitiva no lugar, é o quanto ele considera que o interlocutor é parte fundamental da construção da vida política e, também, do conhecimento sobre o passado.

É verdade que esses quatro livros, que são o eixo deste ensaio - O diabo e a terra de Santa Cruz (1986), de Laura de Mello e Souza; O Tempo Saquarema (1994), de Ilmar Mattos; $A$ invenção do trabalhismo (2005), de Ângela de Castro Gomes; Os Bestializados (1987), de José Murilo de Carvalho -, foram referências constantes na formação de muitos professores e em muitas pesquisas nas pósgraduações que se formaram ao longo da década de 1990. Nessa condição, talvez essa dimensão de dúvida que eles carregam fique pouco evidente. Pior ainda seria afirmar que essa historiografia foi sendo transformada apenas pela mudança de referências teóricas. $\mathrm{O}$ chão desses livros, que abrem para diferentes campos de pesquisa, também foi a redemocratização e, na proporção em que ainda são referências em jogo, esse horizonte ainda é o nosso. 


\section{WRITINGS OF HISTORY IN THE 1980'S: AN ESSAY ON THE HIS- TORICAL HORIZON OF THE (RE)DEMOCRATIZATION}

Abstract: This essay comprehend history of historiography as a path to approach the horizon of the (re)democratization focusing, then, on important references for historians since the 1990s. It should became clear how much our references are from and to (re)democratization and the importance of such horizon. This essay has 3 acts: to understand (re)democratization as a reconstruction of a horizon; 2) the crises of the concept of ideology as a sign of a rupture; 3) some answers given by historians. The question is about the ways through which historiography and democracy reorganized themselves by opening themselves to "new subjects" and to the ongoing historical horizon.

Keywords: 80's. History of historiography. (Re)democratization.

\section{Notas}

${ }^{1} \mathrm{O}$ liberalismo teve fisionomia em sua história mais de uma vez graças a oposição à liberdade em seu sentido antigo. Não que a liberdade moderna apenas se defina como alteridade a alguma coisa, mas que em muitos cenários é assim que ela se manifesta. A pergunta pela diferença entre a liberdade antiga e moderna foi, inclusive, atualizada sistematicamente ao longo do século XX.

\section{Referências}

ARAÚJO, Ricardo Benzaquen. As almas da história. Comentário. In: RIEDEL, Dirce Côrtes (Org.). Narrativa, fíç̧ão \& história. Rio de Janeiro: Imago, 1988. p. $90-111$.

ARAUJO, Valdei. O século XIX no contexto da redemocratização brasileira: a escrita da história oitocentista, balanço e desafios. In: ARAUJO, V. L.; OLIVEIRA, M. da Glória (Org.). Disputas pelo passado: história e historiadores no império do Brasil. Ouro Preto: UFOP, 2012. v. 1.

CARVALHO, José Murilo de. Os Bestializados: o Rio de Janeiro e a república que não foi. São Paulo: Companhia das Letras, 1987.

CEZAR, Temístocles. Hamlet Brasileiro: ensaio sobre giro linguístico e indeterminação historiográfica (1970-1980). História da historiografia, Ouro Preto, n. 17, p. 440-461, abr. 2015.

Anos 90, Porto Alegre, v. 24, n. 46, p. 159-181, dez. 2017 
Escritas da história nos anos 1980: um ensaio sobre o horizonte...

CHAKRABARTY, Dipesh. Provincializing Europe: postcolonial thought and historical difference. Princeton: Princeton University, 2000.

CHAUÍ, Marilena. Cultura e democracia: o discurso competente e outras falas. 4. ed. São Paulo: Cortez, 1989.

. O que é ideologia?. São Paulo: Brasiliense, 1981.

CHAUÍ, Marilena; FRANCO, Marya Sylvia. Ideologia e mobilização popular. Rio de Janeiro: Paz e Terra; Centro de Estudos de Cultura Contemporânea, 1978.

COUTINHO, Carlos Nelson. A democracia como valor universal: notas sobre a questão democrática no Brasil. São Paulo: Livraria Ciências Humanas, 1980.

DECCA, Edgar. 1930: o silêncio dos vencidos. São Paulo: Brasiliense, 1981.

FAORO, Raimundo. Prefácio. In: BENEVIDES, Maria V.; LAMOUNIER, Bolivar; WEFFORT, Francisco C. (Org.). Direito, cidadania e participação. São Paulo: T. A. Queiroz, 1981.

FERNANDES, Florestan. A constituição inacabada. São Paulo: Estação Liberdade, 1989.

FICO, Carlos; POLITO, Ronald. A história no Brasil (1980-1989): Elementos para uma avaliação historiográfica. Ouro Preto: UFOP, 1992.

GADAMER, Hans-Georg. Ciência histórica e linguagem. In: GADAMER, HansGeorg. Hermenêutica em Retrospectiva: a posição da filosofia na sociedade. Petrópolis: Vozes, 2007. p. 59-68.

GOMES, Ângela de Castro. A invenção do trabalhismo. Rio de Janeiro: FGV, 2005. GORENDER, Jacob. Combate nas trevas. A esquerda brasileira: das ilusões à luta armada. São Paulo: Ática, 1987.

GRAMSCI, Antônio. Os intelectuais e a organização da cultura. Tradução de Carlos Nelson Coutinho. Rio de Janeiro: Civilização Brasileira, 1968.

KONDER, Leandro. A democracia e os comunistas no Brasil. Rio de Janeiro: Graal, 1980.

KOSELLECK, Reinhart. Critério do conceito moderno de revolução. In:

Futuros Passados: contribuição à semântica dos tempos históricos. Rio de Janeiro: Contraponto; PUC-Rio, 2006. p. 61-78.

LAMOUNIER, Bolivar. Partidos políticos e consolidação democrática: o caso brasileiro. São Paulo: Brasiliense, 1986.

LAMOUNIER, Bolivar; WEFFORT, Francisco C.; BENEVIDES, Maria Victoria (Org.). Direito, cidadania e participação. São Paulo: T. A. Queiroz, 1981.

Anos 90, Porto Alegre, v. 24, n. 46, p. 159-181, dez. 2017 
LEAL, Victor Nunes. Coronelismo, enxada e voto: o município e o regime representativo no Brasil. São Paulo: Companhia das Letras, 2012.

MATTOS, Ilmar Rohloff. O Tempo Saquarema: a formação do Estado Imperial. Rio de Janeiro: Access, 1994.

NOBRE, Marcos. Choque de Democracia: razões da revolta (E-book). São Paulo: Companhia das Letras, 2013.

PALTÍ, Elias José. Verdades y sabres del marxismo. Buenos Aires: Fondo de Cultura Económica, 2010.

RAMOS, Igor Guedes. Genealogia de uma operação historiográfica: as apropriações dos pensamentos de Edward Palmer Thompson e de Michel Foucault pelos historiadores brasileiros na década de 1980. 2014. 543 f. Tese (Doutorado em História)-Universidade Estadual Paulista, Assis, 2014.

ROUQUIÉ, Alain; LAMONIER, Bolivar; SCHVARZER, Jorge (Org.). Como renascem as democracias. São Paulo: Brasiliense, 1985.

SÁCRISTAN, Manuel. Advertencia. In: GRAMSCI, Antônio. Antología: selección y notas de Manuel Sacristán. México: Akal, 1970.

SADER, Eder. Quando novos personagens entraram em cena: experiências e lutas dos trabalhadores da grande São Paulo 1970-1980. Rio de Janeiro: Paz e Terra, 1988.

SALLES, Ricardo. Gramsci para Historiadores. História da Historiografia, n. 10, p. 211-228, 2012.

SANTOS, P.; NICODEMO, T.; PEREIRA, M. Historiografias periféricas em perspectiva global ou transnacional: eurocentrismo em questão. Estudos Históricos, Rio de Janeiro, v. 30, n. 60, p. 161-186, 2017.

SODRÉ, Nelson Werneck. Contribuição à história do PCB. São Paulo: Global, 1984.

SOUZA, Laura de Mello. O diabo e a terra de Santa Cruz. São Paulo: Companhia das Letras, 1986.

VERSIANI, Maria Helena. Constituinte de 1987/1988: a sociedade brasileira vive a democracia. In: QUADRAT, Samantha Viz (Org.). Não foi tempo perdido: os anos 80 em debate. Rio de Janeiro: 7 Letras, 2014.

Recebido em: 13/07/2017

Aprovado em: 05/10/2017 